SILVA, PHS; CECÍLIO FILHO, AB; REIS, IS; NASCIMENTO, CS; NASCIMENTO, CS. 2021. Rocket plants in response to nitrogen concentration in nutrient solution. Horticultura Brasileira 39: 341-345. DOI: http://dx.doi.org/10.1590/s0102-0536-20210316

\title{
Rocket plants in response to nitrogen concentration in nutrient solution
}

\author{
Paulo Henrique S Silva ${ }^{1 * \mathbb{D}}$; Arthur Bernardes Cecílio Filho ${ }^{1} \mathbb{D}$; Isaias dos $S$ Reis ${ }^{1} \mathbb{D}$; Carolina $S$ Nascimento \\ 1D; Camila $S$ Nascimento ${ }^{1} \mathbb{D}$
}

'Universidade Estadual Paulista 'Júlio de Mesquita Filho' (UNESP), Jaboticabal-SP, Brasil; phsoares18@yahoo.com.br (*author for correspondence); arthur.cecilio@unesp.br; isaias.agro@hotmail.com; carolina.seno@yahoo.com.br; camilaseno@gmail.com

\begin{abstract}
Nitrogen $(\mathrm{N})$ is the second most accumulated nutrient in rocket. This nutrient greatly affects growth, productivity and quality of the vegetable. Rocket is the second most widely grown leafy vegetable in hydroponic system; however, no studies on how N concentration in nutrient solution affects this crop can be found in literature. We studied four concentrations $\left(79.2 ; 118.8 ; 158.4\right.$ and $237.6 \mathrm{mg} \mathrm{L}^{-1}$ of $\left.\mathrm{N}\right)$ in a randomized block design with five replicates. Maximum number of leaves, leaf area, dry mass and productivity of rocket cv. 'Folha larga' were obtained with the highest $\mathrm{N}$ concentration. The rocket quality, evaluated by the nitrate content, was maximum with $210.2 \mathrm{mg} \mathrm{L}^{-1}$ of $\mathrm{N}$ and its value in the concentration which maximized productivity is in the acceptable range for vegetables; so, it is recommended to grow rocket with $237.6 \mathrm{mg} \mathrm{L}^{-1}$ of $\mathrm{N}$ in the nutrient solution.
\end{abstract}

Keywords: Eruca sativa, soil-free cultivation, hydroponics, leafy vegetables, nitrate.

\section{RESUMO}

Resposta da rúcula à concentração de nitrogênio na solução nutritiva

O nitrogênio $(\mathrm{N})$ é o segundo nutriente mais acumulado pela rúcula, o qual afeta sobremaneira o crescimento, produtividade e qualidade desta hortaliça. A rúcula é a segunda hortaliça folhosa mais cultivada em hidroponia; porém, não há estudos sobre como a concentração do $\mathrm{N}$ na solução nutritiva a afeta, tendo sido este o objetivo do presente estudo. Quatro concentrações (79,2;118,8;158,4 e $237,6 \mathrm{mg} \mathrm{L}^{-1} \mathrm{de} \mathrm{N}$ ) foram avaliadas em delineamento experimental de blocos casualizados, com cinco repetições. Máximos número de folhas, área foliar, massa seca e produtividade da rúcula 'Folha larga' foram obtidos com a maior concentração de N. A qualidade da rúcula, avaliada pelo teor de nitrato, foi máxima com $210,2 \mathrm{mg} \mathrm{L}^{-1}$ de N. Seu valor na concentração que maximizou a produtividade encontra-se na faixa aceitável para hortaliças; de modo que se recomenda o cultivo da rúcula com $237,6 \mathrm{mg} \mathrm{L}^{-1}$ de $\mathrm{N}$ na solução nutritiva.

Palavras-chave: Eruca sativa, cultivo sem solo, hidroponia, hortaliça folhosa, nitrato.

Received on January 26, 2021; accepted on July 20, 2021

$\mathrm{R}^{\mathrm{s}}$ ocket (Eruca sativa) is a very popular leafy vegetable, consumed in natura, in salads or in pizzas (Aguiar et al., 2014; Schiattone et al., 2018).

The growing area has expanded and the number of hydroponic growers has increased, as the market demand has grown. Considering the leafy vegetables, rocket is the second most cultivated under hydroponic system, being lettuce the first one (Matos et al., 2016). However, for a successful cultivation in hydroponic system, an appropriate nutrient solution and management of this solution are necessary, since they directly influence in production and quality of hydroponic crops (Genuncio et al., 2011; Guerra et al., 2011). For leafy vegetables cultivation, the nutrient solutions must have very high nitrogen (N) concentrations (Urlić et al., 2017) and, unfortunately, we cannot find in literature one nutrient solution which would be established for the nutritional demand of rocket. In general, the nutrient solution recommended for other leafy vegetables is used, as proposed by Furlani (1998) and Faquin \& Furlani (1999).

Considering the nutrients, $\mathrm{N}$ is an extremely important one, as it is the second most accumulated nutrient in rocket (Grangeiro et al., 2011), showing effect on growing and productivity, as well as on quality (Petropoulos et al., 2016). Researches about $\mathrm{N}$ for the rocket crop under soil-free cultivation system are still scarce, but studies on field conditions are common, though (Steiner et al., 2011; Yoruk et al., 2018; Barros Júnior et al., 2020; Silva et al., 2020).

On the other hand, high $\mathrm{N}$ availability can increase rocket productivity, but can also affect negatively the quality of this crop. The vegetables produced under this system, using concentrated $\mathrm{N}$ nutrient solutions, can accumulate nitrate $\left(\mathrm{NO}_{3}^{-}\right)$in excess in leaves (Andriolo, 2020). However, the accumulation of $\mathrm{NO}_{3}^{-}$depends on several factors, such as management, amount and type of nitrogen fertilizers and light intensity (Faquin, 2008). $\mathrm{N}$ availability is one of the main factors affecting and contributing to increase $\mathrm{NO}_{3}{ }^{-}$mainly in the leaves of the plants. Since leaf is the edible part of rocket, a special monitoring of $\mathrm{N}$ is essential in order to avoid consumer intoxication. This compost is associated to a possible formation of carcinogenic and mutagenic compounds in the human body (Ranasinghe \& Marapana, 2018; 
Moazeni et al., 2020).

Among the leafy vegetables, the production of rocket to be used in ready-to-eat salads is increasing in order to meet the market demand; nevertheless, being rocket known as a nitrate hyperaccumulating species, great attention is needed, especially, in the precise management of nitrogen fertilization (Mola et al., 2019). Thus, Cavarianni et al. (2008) studied nitrogen concentrations in nutrient solution $(60.8$ - $\left.243.5 \mathrm{mg} \mathrm{L}^{-1}\right)$ and verified a linear response in rocket leaf nitrate content (3378 $\mathrm{mg} \mathrm{kg}^{-1}$ ), when $\mathrm{N}$ concentration in nutrient solution increases, which can compromise the quality of the vegetable.

Given the above, this study aimed to evaluate the effect of $\mathrm{N}$ concentration in the nutrient solution regarding productivity and quality of rocket grown under hydroponic system.

\section{MATERIAL AND METHODS}

\section{Time and location}

The experiment was carried out from July 3 to August 16, 2018, in nutrient film technique (NFT) hydroponic system, at UNESP, Jaboticabal campus, São Paulo, Brazil $\left(21^{\circ} 15^{\prime} 22^{\prime} \mathrm{S}, 48^{\circ} 15^{\prime} 58^{\prime \prime} \mathrm{W}, 615\right.$ $\mathrm{m}$ altitude).

The region climate is classified as Aw according to Köppen-Geiger. Tropical climate: rainy and hot summer, dry winter, mild temperatures, considering the average temperature of the coldest month above $18^{\circ} \mathrm{C}$ (André \& Garcia, 2015). During the experiment, the maximum, average and minimum temperature were $36.4^{\circ} \mathrm{C}$, $28.5^{\circ} \mathrm{C}$ and $21.5^{\circ} \mathrm{C}$, maximum, average and minimum relative humidity were $64.7 \%, 38.6 \%$ and $13.1 \%$, respectively, solar average and maximum radiation were 16.1 and $726.3 \mathrm{MJ} \mathrm{m}^{-2}$, respectively. The data were obtained in an agrometeorological microstation installed inside the greenhouse at FCAVUNESP, Jaboticabal-SP.

Treatments and experimental design

We evaluated four treatments related to nitrogen concentration in the nutrient solution: $79.2 ; 118.8 ; 158.4$ and $237.6 \mathrm{mg}$ $\mathrm{L}^{-1}$. The experimental design used was randomized blocks with five replicates.
The experimental unit consisted of a bench with five $1.3 \mathrm{~m}$-long channels. The useful area of the experimental unit for data collection corresponded to the three central channels of the bench, excluding the first and last plant of each channel.

Installation and conduction of the experiment

Rocket cultivar 'Folha Larga' was sown on July 3 in phenolic foam boards measuring $2 \times 2 \times 2 \mathrm{~cm}$, previously washed under running water for approximately 10 minutes, in order to clean any kind of residue. During germination, these boards were kept in a greenhouse, under sprinkler irrigation system, being irrigated with pure water (Phase I).

Eight days after sowing (8 DAS), when the seedlings showed expanded cotyledons, the phenolic foam cells were individualized and seedlings taken to the polypropylene channels, $5-\mathrm{cm}$ wide, in NFT system (Phase II).

The channels denominated "nursery", had $5 \%$ slope. The nutrient solution supply was intermittent, alternating 15 minutes with circulation and 15 minutes without circulation (6 a.m. to 6 p.m.). This period corresponded to the initial growing of the plants, before being taken to definite channels. In this phase, the complete nutrient solution proposed by Furlani (1998) was used: concentrations of $750\left[\mathrm{Ca}\left(\mathrm{NO}_{3}\right)_{2}\right] ; 500\left(\mathrm{KNO}_{3}\right) ; 150$ $\left(\mathrm{NH}_{4} \mathrm{H}_{2} \mathrm{PO}_{4}\right)$ and $400\left(\mathrm{MgSO}_{4}\right) \mathrm{g} 1000$ $\mathrm{L}^{-1}$. Micronutrients were applied in concentrations, recommended by the author: $1.76\left(\mathrm{H}_{3} \mathrm{BO}_{3}\right) ; 0.15\left(\mathrm{CuSO}_{4}\right)$; $1.5\left(\mathrm{MnSO}_{4}\right) ; 0.30\left(\mathrm{ZnSO}_{4}\right)$ and 0.10 $\left(\mathrm{NH}_{4}\right)_{6} \mathrm{Mo}_{7} \mathrm{O}_{24} \mathrm{~g} \mathrm{~L}^{-1}$ and $60 \mathrm{~mL}$ of $\mathrm{Fe}$ for $1000 \mathrm{~L}^{-1}$.

At 24 DAS, after showing three fully expanded leaves, the seedlings were transplanted into the final growing channels, $10-\mathrm{cm}$ diameter and $5 \%$ slope (Phase III), spacing $0.25 \mathrm{~m}$ between channels and $0.05 \mathrm{~m}$ between plants. We used the nutrient solution proposed by Furlani (1998), with modifications to meet $\mathrm{N}$ concentrations in the nutrient solution (Table 1).

Micronutrients were applied in the concentrations recommended by Furlani (1998): $1.8 \mathrm{~g} \mathrm{~L}^{-1} \mathrm{H}_{3} \mathrm{BO}_{3} ; 0.1 \mathrm{~g}$ $\mathrm{L}^{-1} \mathrm{CuSO}_{4} ; 1.5 \mathrm{~g} \mathrm{~L}^{-1} \mathrm{MnSO}_{4} ; 0.11 \mathrm{~g} \mathrm{~L}^{-1}$
$\left(\mathrm{NH}_{4}\right)_{6} \mathrm{Mo}_{7} \mathrm{O}_{24} ; 0.30 \mathrm{~g} \mathrm{~L}^{-1} \mathrm{ZnSO}_{4}$ and 60 $\mathrm{mL} 1000 \mathrm{~L}^{-1}$ of iron $(\mathrm{Fe})$.

The solution was pumped continuously by submerged pumps (one per plot) (Chosen $\AA$ brand, model Power Head CX-300) at $1000 \mathrm{~L} \mathrm{~h}^{-1}$ flow. The irrigation system was controlled by an electronic timer, activated from 7 a.m. to 6 p.m. (15 minutes with circulations and 15 minutes without circulation). The $\mathrm{pH}$ was measured daily, using a $\mathrm{pHep}{ }^{\circledR}+$ pocket-sized $\mathrm{pHmeter}$ and the electrical conductivity (CE) with a DIST4 digital conductivity meter. The $\mathrm{pH}$ was kept from 5.5 to 6.5 , using sodium hydroxide or hydrochloric acid, in order to increase or reduce $\mathrm{pH}$, respectively. The nutrient solution was renewed when $\mathrm{CE}$ of the treatments reached $70 \%$ of the initial $\left.\mathrm{CE}(\mathrm{dS} \mathrm{m})^{-1}\right)$.

\section{Evaluated traits}

To evaluate agronomic traits of the rocket, five sets of plants were collected randomly in the useful area of each plot. Height, number of leaves, leaf area, shoot dry mass, leaf nitrogen content, productivity and nitrate content were evaluated, 20 days after the beginning of Phase III. Plant height was measured using a measuring tape $(0.5 \mathrm{~cm}$ above the plant collar to the highest leaf), the leaves were counted and leaf area was obtained with the aid of the leaf area integrator LI-COR 3100. To obtain shoot dry mass, plants were washed and dried in an oven with forced air circulation at $65-70^{\circ} \mathrm{C}$ until reaching constant mass, then they were weighed using a semi-analytical scale (two decimal places).

Fresh mass was obtained right after harvest, between 6 and 7 a.m. Productivity was estimated by the product of fresh mass and planting density $\left(80\right.$ plants $\left.\mathrm{m}^{-2}\right)$. Shoot dry mass was used to evaluate $\mathrm{N}$ leaf content, according to Miyazawa et al. (2009) method.

To determine the nitrate content of the shoot part of rocket, six plants were collected randomly in the useful area of each plot, between 5:30 and 6:30 hours. Nitrate was determined according to Mantovani et al. (2005): $0.2 \mathrm{~g}$ of leaf dry matter and $20 \mathrm{~mL}$ deionized water was placed in $50 \mathrm{~mL}$ Falcon tubes. The tubes remained in water bath at 
$60 \pm 5^{\circ} \mathrm{C}$ for one hour, being agitated every 15 minutes. The samples were filtered through fast filter paper. The authors took $5 \mathrm{~mL}$ of this extract and added $20 \mathrm{~mL}$ deionized water and 0.2 g $\mathrm{MgO}$. Ammonium was converted into ammonia through distillation and the distillate was discarded. Then, we added, in this same extract, 0.4 g Devarda's alloy for the reduction of nitrate to ammonium which, in an alkaline medium, was converted into ammonia, which was entrained by vapors and collected in a beaker containing $10 \mathrm{~mL}$ of $20 \mathrm{~g} \mathrm{~L}^{-1} \mathrm{H}_{3} \mathrm{BO}_{3}$. Afterwards, we quantified $\mathrm{N}$ in the form of ammonium using an automatic titrator (848 Titrino plus $\left.{ }^{\circledR}\right)$ with standard solution of $\mathrm{H}_{2} \mathrm{SO}_{4} 0.00263 \mathrm{~mol} \mathrm{~L}^{-1}$. The nitrate content obtained in the leaf dry mass was converted to $\mathrm{mg}$ of $\mathrm{NO}_{3}{ }^{-}$per $\mathrm{kg}$ of fresh mass, considering $5 \%$ of fresh mass in the rocket.

\section{Statistical analysis}

Obtained data were submitted to variance analysis ( $F$ test, $\mathrm{p}<0.05$ ). Polynomial regression analysis for $\mathrm{N}$ concentration in nutrient solution was performed. An equation with the highest level of significance and determination coefficient was used. The authors used
AgroEstat statistical software (Barbosa \& Maldonado Júnior, 2015).

\section{RESULTS AND DISCUSSION}

$\mathrm{N}$ concentration in the nutrient solution influenced all the evaluated variables (Table 2). Number of leaves, leaf area and shoot dry mass positively responded to the increase of $\mathrm{N}$ concentration in the nutrient solution, using linear equation adjustment, whereas plant height showed the maximum value $(37.7 \mathrm{~cm})$ with 229.5 $\mathrm{mg} \mathrm{L}^{-1}$ of $\mathrm{N}$ (Figure 1). The maximum values for number of leaves, leaf area, shoot dry mass and height were $18 \%$ (+3 leaves per plant), $54 \%\left(+258.3 \mathrm{~cm}^{2}\right)$, $49 \%(+1.3 \mathrm{~g})$ and $23 \%(+7 \mathrm{~cm})$ higher, respectively, comparing with plants grown with lower $\mathrm{N}$ concentration in the nutrient solution $\left(79.2 \mathrm{mg} \mathrm{L}^{-1}\right)$.

In this study, this effect was verified in rocket, since the increase of $\mathrm{N}$ availability in the nutrient solution reflected in an increase of $\mathrm{N}$ content in the leaf and, consequently, in biometric traits (height, leaf area, shoot dry mass), productivity and quality. The results corroborate the information that rocket is very responsive to nitrogen fertilization (Barros Júnior et al., 2011; Grangeiro et al., 2011; Steiner et al., 2011; Benett et al., 2015, 2019; Vieira Filho et al., 2017; Silva et al., 2020).

The highest $\mathrm{N}$ content in the leaf was $28.2 \mathrm{~g} \mathrm{~kg}^{-1}$, reached using $186 \mathrm{mg}$ $\mathrm{L}^{-1}$ of $\mathrm{N}$ in the nutrient solution (Figure 2A). However, this leaf content did not represent the value of $\mathrm{N}$ concentration related to the maximum productivity. This productivity responded linearly and positively to the increase of $\mathrm{N}$ availability in the nutrient solution, maximum $\left(3.89 \mathrm{~kg} \mathrm{~m}^{-2}\right)$ with $27 \mathrm{~g}$ $\mathrm{kg}^{-1}$ of leaf $\mathrm{N}$ concentration (Figure $2 \mathrm{~A}$ ), an increase of $35 \%$ in the crop productivity in relation to plants grown in a nutrient solution with $79.2 \mathrm{mg} \mathrm{L}^{-1}$ of $\mathrm{N}$, with a content of $23.6 \mathrm{~g} \mathrm{~kg}^{-1}$ leaf $\mathrm{N}$ concentration.

Nitrogen concentration which maximized rocket productivity (237.6 $\mathrm{mg} \mathrm{L}^{-1}$ of N) was superior to the one obtained by Cavarianni et al. (2011), 104 $\mathrm{mg} \mathrm{L}^{-1}$ of $\mathrm{N}\left(1.2 \mathrm{~kg} \mathrm{~m}^{-2}\right)$. Nevertheless, the highest productivity obtained was similar to the one verified by Purquerio et al. (2007), 3.0 and $3.3 \mathrm{~kg} \mathrm{~m}^{-2}$, in the field and in a protected environment, respectively.

Table 1. Concentration of nutrients in the nutrient solution. Jaboticabal, UNESP, 2018.

\begin{tabular}{|c|c|c|c|c|c|c|c|c|c|}
\hline \multirow{2}{*}{ Nutrient solution } & SM & NC & NK & MAP & $\mathrm{CC}$ & CK & MKP & NA & \multirow{2}{*}{$\operatorname{AN}\left(\mathrm{mL} 1000 \mathrm{~L}^{-1}\right)$} \\
\hline & \multicolumn{8}{|c|}{$\left(\mathrm{g} 1000 \mathrm{~L}^{-1}\right)$} & \\
\hline $79.2 \mathrm{mg} \mathrm{L}^{-1}$ & 320 & 480 & - & 44 & 84 & 228 & 87 & - & - \\
\hline $118.8 \mathrm{mg} \mathrm{L}^{-1}$ & 320 & 600 & 139 & 76.4 & - & 157 & 48.7 & - & - \\
\hline $158.4 \mathrm{mg} \mathrm{L}^{-1}$ & 320 & 600 & 400 & 120 & - & - & - & - & - \\
\hline $237.6 \mathrm{mg} \mathrm{L}^{-1}$ & 320 & 600 & 292 & - & - & - & 135 & 138 & 68 \\
\hline
\end{tabular}

$\mathrm{SM}=$ Magnesium sulfate $\mathrm{NC}=$ Calcium nitrate $\mathrm{NK}=$ Potassium nitrate $; \mathrm{MAP}=$ Phosphate monoammonium; $\mathrm{CC}=\mathrm{Calcium}$ chloride $; \mathrm{CK}$ $=$ Potassium chloride; $\mathrm{MKP}=$ Monobasic potassium phosphate; $\mathrm{NA}=$ Ammonium nitrate; $\mathrm{AN}=\mathrm{Nitric}$ acid.

Table 2. Plant height (AP), number of leaves (NF), leaf area (AF), shoot dry mass (MSPA), leaf nitrogen content (N), productivity (PROD) and leaf nitrate content $\left(\mathrm{NO}_{3}^{-}\right)$of rocket in relation to the nitrogen concentration $(\mathrm{N})$ in the nutrient solution. Jaboticabal, UNESP, 2018.

\begin{tabular}{|c|c|c|c|c|c|c|c|}
\hline $\begin{array}{l}\mathbf{N} \\
\left(\mathbf{m g ~ L ^ { - 1 }}\right) \\
\end{array}$ & $\begin{array}{c}\mathrm{AP} \\
(\mathrm{cm})\end{array}$ & $\begin{array}{c}\text { NF } \\
\text { (leaves plant }^{-1} \text { ) }\end{array}$ & $\begin{array}{c}\text { AF } \\
\left(\mathrm{cm}^{2} \text { plant }^{-1}\right) \\
\end{array}$ & $\begin{array}{c}\text { MSPA } \\
\left.\text { (g plant }^{-1}\right)\end{array}$ & $\begin{array}{c}\mathrm{N} \\
\left(\mathrm{g} \mathrm{kg}^{-1}\right)\end{array}$ & $\begin{array}{c}\text { PROD } \\
\left(k^{\left(k^{2} ~ m^{-2}\right)}\right. \\
\end{array}$ & $\begin{array}{c}\mathrm{NO}_{3}^{-} \\
\left(\mathrm{g} \mathrm{kg}^{-1}\right)\end{array}$ \\
\hline 79.2 & 30.73 & 12.30 & 463.56 & 2.34 & 23.7 & 2.74 & 1004.62 \\
\hline 118.8 & 33.63 & 12.50 & 537.69 & 2.99 & 26.2 & 3.22 & 2083.58 \\
\hline 158.4 & 35.49 & 13.95 & 655.45 & 3.50 & 27.9 & 3.60 & 3259.12 \\
\hline 237.6 & 36.17 & 14.35 & 718.05 & 3.66 & 27.0 & 3.78 & 3391.06 \\
\hline$F$ values & $10.26^{* *}$ & $19.28 * *$ & $14.8^{* *}$ & $5.99 * *$ & $13.22 * *$ & $8.39 * *$ & $41.17 * *$ \\
\hline CV (\%) & 4.99 & 3.93 & 11.49 & 17.28 & 4.29 & 10.65 & 16.03 \\
\hline
\end{tabular}

$* *$ Significant at $1 \%$ probability $(\mathrm{p}<0.01)$. 


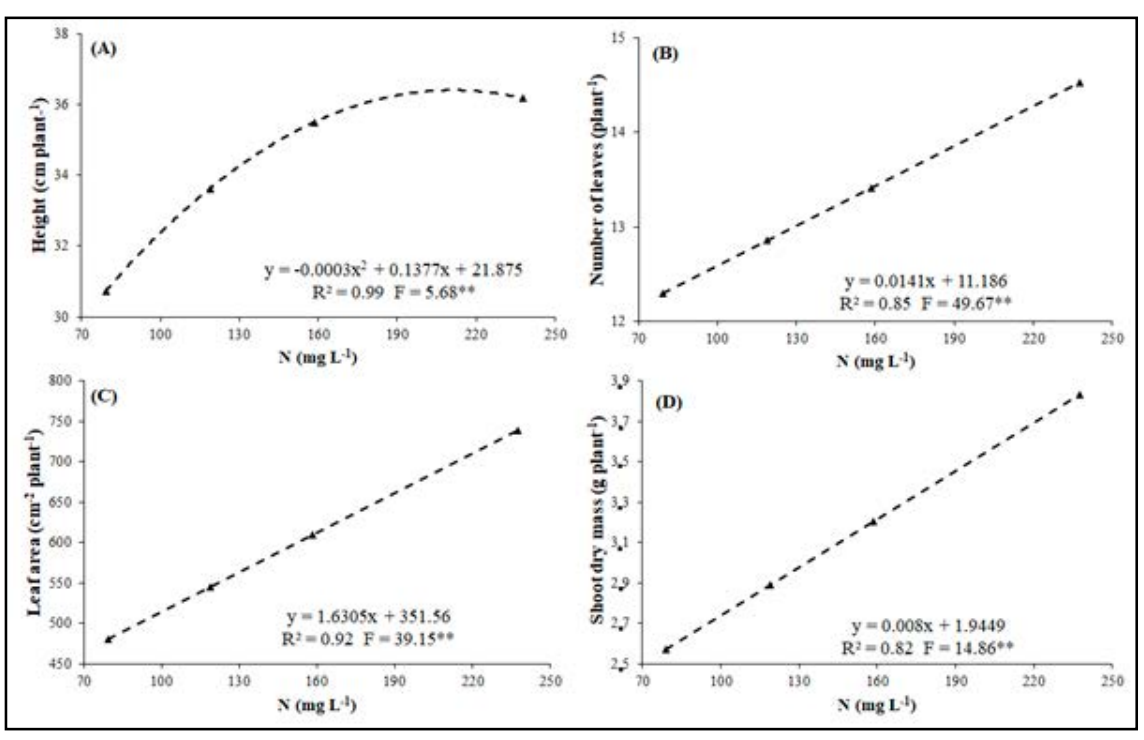

Figure 1. Height (A), number of leaves (B), leaf area (C), shoot dry mass (D) of rocket in relation to the nitrogen concentration $(\mathrm{N})$ in the nutrient solution. Jaboticabal, UNESP, 2018.

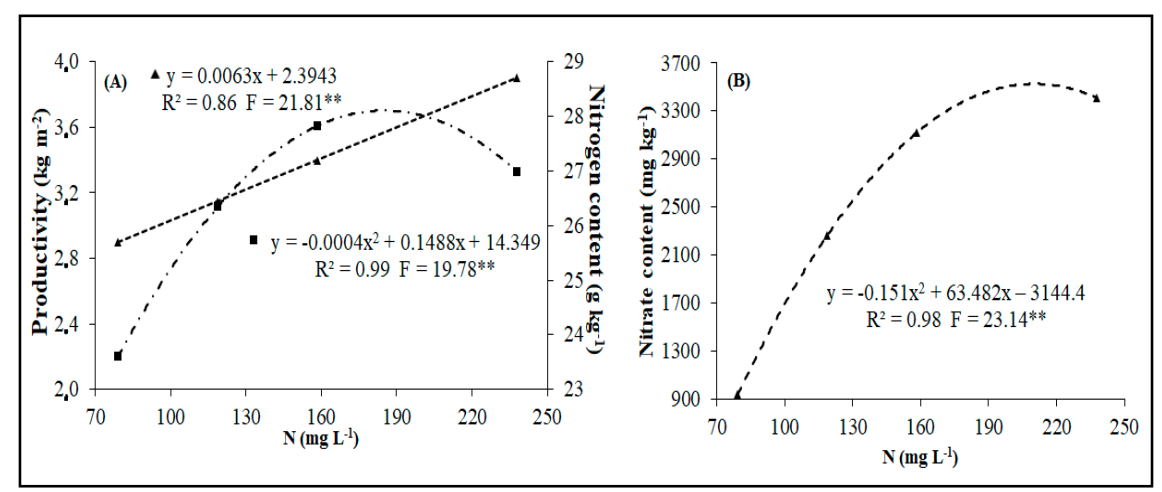

Figure 2. Nitrogen content $(\boldsymbol{\square})$ and productivity $(\boldsymbol{\Delta})$ (A) and nitrate contente (B) of rocket in relation to the nitrogen concentration $(\mathrm{N})$ in the nutrient solution. Jaboticabal, UNESP, 2018.

According to Trani et al. (2014), appropriate leaf $\mathrm{N}$ concentration for rocket is between 40 and $50 \mathrm{~g} \mathrm{~kg}^{-1}$, which is related to a sampling period between half and two thirds of the cycle. The leaf contents used in this study were obtained in harvest and, probably, this can explain the contents lower than the appropriate rate, since no deficiency symptoms were observed, even in the lowest concentration in the nutrient solution. The highest $\mathrm{N}$ content in shoot dry mass was obtained using a concentration estimated of $186 \mathrm{mg}$ $\mathrm{L}^{-1}$ whereas the highest productivity was observed with the highest $\mathrm{N}$ concentration in the nutrient solution. This behavior can be explained by the nutrient diluting effect. According to Maia et al. (2005), this happens when the relative growth rate of the dry matter is superior to the relative uptake rate of the nutrient, which is confirmed by the response of the dry mass accumulation of the rocket, provided by an increase of $\mathrm{N}$ concentration in the solution (Figure 1D).

Plants well nourished with $\mathrm{N}$ had a positive effect on rocket productivity (Figure 2A), showed a negative effect on quality, though (Figure 2B). The results are in accordance with the observed by Purquerio et al. (2007) and Steiner et al. (2011) and also that N supply is one of the main factors which promote greater nitrate accumulation (Ceylan et al., 2002; Guadagnin et al., 2005; Barros Júnior et al., 2020). This conflict caused by nitrogen fertilization deserves attention from researchers for establishing $\mathrm{N}$ concentration in the nutrient solution.
In relation to linear adjustment for productivity averages (Figure 2A), the maximum value was not reached; it can be increased with an increase of $\mathrm{N}$ concentration in the nutrient solution. However, the limit of this concentration should not be the species' ability to maximize productivity; but, the nitrate content accumulated in rocket leaves should be taken in consideration. This compost is associated with the possibility of forming carcinogenic and mutagenic compounds in the human body (Tamme et al., 2010; Ahmed et al., 2017; Moazeni et al., 2020). In most diets, vegetables generally contribute more than $70 \%$ of the total nitrate ingested (Guadagnin et al., 2005).

Considering the nitrate content, Brazil has no legislation for the presence of nitrate in vegetables; however, the European Union established that for rocket produced from October to March and from April to September, the maximum contents should be 7000 and $6000 \mathrm{mg} \mathrm{kg}^{1}$ (fresh mass), respectively (UE, 2011). The nitrate content in the shoot fresh mass of rocket, considering concentration of $237.6 \mathrm{mg} \mathrm{L}^{-1}$ which maximized productivity, is below the limit established for the crop, offering no risk whatsoever to health.

The increase of $\mathrm{N}$ concentration in the nutrient solution provided greater nitrate accumulation in the rocket (Figure 2B). The maximum nitrate content $\left(3527.70 \mathrm{mg} \mathrm{kg}^{-1}\right)$ in the shoot fresh mass of the crop was obtained in the concentration $210.2 \mathrm{mg} \mathrm{L}^{-1}$ of $\mathrm{N}$ in the nutrient solution, an increase of $277 \%$ in relation to the lowest concentration. Using $237.6 \mathrm{mg} \mathrm{L}^{-1}$ of $\mathrm{N}$, dose which maximized the productivity, nitrate content was $3414.4 \mathrm{mg} \mathrm{kg}^{-1}$.

Thus, the increase of $\mathrm{N}$ concentration provided higher plants, greater number of leaves, leaf area, shoot dry mass and leaf nitrogen content. Nitrate content did not reach the maximum limit established for the crop and so, the highest $\mathrm{N}$ concentration (237.6 $\mathrm{mg} \mathrm{L}^{-1}$ of $\mathrm{N}$ ) can be used to maximize productivity.

\section{ACKNOWLEDGMENTS}

To coordination of improvement 
of higher education personnel, Brazil (CAPES), Financing Code 001, for the scholarship for the first author and to the national council for scientific and technological development (CNPq) for the scholarship for the second authors.

\section{REFERENCES}

AGUIAR, ATE; GONÇALVES, C; PATERNIANI, MEAGZ; TUCCI, MLSA; CASTRO, CEF. 2014. Instruções agrícolas para as principais culturas econômicas. Campinas: IAC (Boletim 200, 2-452).

AHMED, M; RAUF, M; MUKHTAR, Z; SAEED, NA. 2017. Excessive use of nitrogenous fertilizers: an unawareness causing serious threats to environment and human health. Environmental Science and Pollution Research 24: 26983-26987.

ANDRÉ, RGB; GARCIA, A. 2015. Alguns aspectos climáticos do município de Jaboticabal-SP. Nucleus 12: 263-269.

ANDRIOLO, JL. 2020. Olericultura geral. Editora UFSM: Fundação de Apoio à Tecnologia e Ciência.

BARBOSA, JC; MALDONADO JÚNIOR, W. 2015. Experimentação agronômica \& AgroEstat: sistemas para análises estatísticas de ensaios agronômicos. Multipress. p.76.

BARROS JÚNIOR, AP; CECÍLIO FILHO, AB; RESENDE, BLA; LINS, HA. 2020. Acúmulo de nitrato na alface e rúcula em resposta à adubação nitrogenada das culturas em consórcio. Revista Caatinga 33: 260-265.

BARROS JÚNIOR, AP; CECÍLIO FILHO, AB; REZENDE, BLA; PÔRTO, DR; PRADO, RDM. 2011. Nitrogen fertilization on intercropping of lettuce and rocket. Horticultura Brasileira 29: 398-403.

BENETT, KSS; BENETT, CGS; SANTOS, GG; COSTA, E. 2015. Effects of hydrogel and nitrogen fertilization on the production of arugula in successive crops. African Journal of Agricultural Research 10: 2601-2607.

BENETT, KSS; XAVIER, RC; BENETT, CGS; SALOMÃO, LC; SELEGUINI, A; CANTUARIO, FS; MARTINS, AS. 2019. Nitrogen application in arugula culture. Journal of Agricultural Science 11: 385-391.

CAVARIANNI, RL; CECÍLIO FILHO, AB; CAZETTA, JO; MAY, A; CORRADI, MM. 2008. Concentrações de nitrogênio na solução nutritiva e horários de colheita no teor de nitrato em rúcula. Caatinga 21: 44-49.

CAVARIANNI, RL; CORRADI, MM; CECÍLIO FILHO, AB; MAY, A. 2011. Produção de cultivares de rúcula em função da concentração de nitrogênio na solução nutritiva. Available at $<$ http://www.abhorticultura.com.br/biblioteca/ arquivos/Download/Biblioteca/44_417.pdf>. Accessed October 15, 2020.

CEYLAN, S; MORDOGAN, N; CAKICI, H; YOLDAS, F. 2002. Effects of different nitrogen levels on the yield and nitrogen accumulation in the rocket. Asian Journal of Plant Sciences 1: 482-483.
EUROPEAN UNION. 2011. Commission Regulation (EC) No 1258/2011 of 2 December 2011 amending Regulation (EC) No 1881/2006 as regards maximum levels for nitrates in foodstuffs setting. Official Journal of the European Union 320: 15-17. Available at $<$ https://eur-lex.europa.eu/LexUriServ/ LexUriServ.do?uri=OJ:L:2011:320:0015:0 017:EN:PDF>. Accessed October 15, 2020.

FAQUIN, V; ANDRADE, AT. 2004. Nutrição mineral e diagnose do estado nutricional de hortaliças. Lavras: UFLA/FAEPE. 88p.

FAQUIN, V; FURLANI, PR. 1999. Cultivo de hortaliças de folhas em hidroponia em ambiente protegido. Informe Agropecuário 20: 99-104.

FURLANI, PR. 1998. Instruções para o cultivo de hortaliças de folhas pela técnica de hidroponia - NFT.

GENUNCIO, GDC; SILVA, RAC; SÁ, NM; MARY, W; ZONTA, E. 2011. Produtividade de rúcula hidropônica cultivada em diferentes épocas e vazões de solução nutritiva. Horticultura Brasileira 29: 605-608.

GRANGEIRO, LC; OLIVEIRA, FCL; NEGREIROS, MZ; MARROCOS, STP; LUCENA, RRM; OLIVEIRA, RA. 2011. Crescimento e acúmulo de nutrientes em coentro e rúcula. Revista Brasileira de Ciências Agrárias 6: 11-16.

GUADAGNIN, SG; RATH, S; REYES, FGR. 2005. Evaluation of the nitrate content in leaf vegetables produced through different agricultural systems. Food additives and contaminants 22: 1203-1208.

GUERRA, GMP; LUZ, JMQ; HABER, LL; SILVA, MAD. 2011. Cultivo hidropônico de rúcula em diferentes concentrações de solução nutritiva, em sistema NFT. Available at $<$ http://www.abhorticultura.com.br/biblioteca/ arquivos/download/biblioteca/44_647.pdf>. Accessed September 15, 2020.

MAIA, CE; MORAIS, ERC; FILHO, FDQP; GUEYI, HR; MEDEIROS, JF. 2005. Teores foliares de nutrientes em meloeiro irrigado com águas de diferentes salinidades. Revista Brasileira de Engenharia Agrícola e Ambiental 9: 292-295.

MANTOVANI, JR; CRUZ, MCP; FERREIRA, ME; BARBOSA, JC. 2005. Comparação de procedimentos de quantificação de nitrato em tecido vegetal. Pesquisa Agropecuária Brasileira 40: 53-59.

MATOS, TS; NASCIMENTO, EC; GENUNCIO, GC. 2016. Consumo de rúcula está em plena expansão. Revista Campo \& Negócios. Available at $<$ https://revistacampoenegocios. com.br/consumo-de-rucula-esta-em-plenaexpansao/\#: :text=R\%C3\%BAcula\%20hidr op $\% \mathrm{C} 3 \%$ B 4 nica\&text $=$ Atualmente $\% 2 \mathrm{C} \% 20$ a $\% 20 \mathrm{r} \% \mathrm{C} 3 \%$ BAcula $\% 20 \% \mathrm{C} 3 \% \mathrm{~A} 9 \% 20$ a,furos $\% 20$ utilizados $\% 20$ para $\% 200 \% 20$ ma\%C3\%A7o).>. Accessed October 20, 2020.

MIYAZAWA, M; PAVAN, MA; MURAOKA, T; CARMO, CAFS; MELO, WJ. 2009. Análise química de tecido vegetal. In: Silva FC (ed). Manual de análises químicas de solos, plantas e fertilizantes. 2. ed. Brasília: EMBRAPA. p.191-233.

MOAZENI, M; HEIDARI, Z; GOLIPOUR, S; GHAISARI, L; SILLANPÄÄ, M;
EBRAHIMI, A. 2020. Dietary intake and health risk assessment of nitrate, nitrite, and nitrosamines: a Bayesian analysis and Monte Carlo simulation. Environmental Science and Pollution Research 1-13.

MOLA, I; OTTAIANO, L; COZZOLINO, E; SENATORE, M; GIORDANO, M; NAKHEL, C; SACCO, A; ROUPHAEL, Y; COLLA, G; MORI, M. 2019. Plant-based biostimulants influence the agronomical, physiological, and qualitative responses of baby rocket leaves under diverse nitrogen conditions. Plants 8: 522.

PETROPOULOS, AS; CHATZIEUSTRATIOU, E; CONSTANTOPOULOU, E; KAPOTIS, G. 2016. Yield and quality of lettuce and rocket grown in floating culture system. Notulae Botanicae Horti Agrobotanici Cluj-Napoca 44: 603-612.

PURQUERIO, LFV; DEMANT, LAR; GOTO, R; VILLAS BOAS, RL. 2007. Efeito da adubação nitrogenada de cobertura e do espaçamento sobre a produção de rúcula. Horticultura Brasileira, 25: 464-470.

RANASINGHE, RASN; MARAPANA, RAUJ. 2018. Nitrate and nitrite content of vegetables: A review. Journal of Pharmacognosy and Phytochemistry 7: 322-328.

SCHIATTONE, MI; VIGGIANI, R; VENERE, D; SERGIO, L; CANTORE, V; TODOROVIC, M; PERNIOLA, M; CANDIDO, V. 2018. Impact of irrigation regime and nitrogen rate on yield, quality and water use efficiency of wild rocket under greenhouse conditions. Scientia Horticulturae 229: 182-192.

SILVA, PHS; PALARETTI, LF; CECÍLIO FILHO, AB; SILVA, YF. 2020. Nitrogen levels via fertigation and irrigation depths in the arugula culture. Horticultura Brasileira 38: 343-349.

STEINER, F; PIVETTA, LA; CASTOLDI, G; PIVETTA, LG; FIOREZE, S. 2011. Produção de rúcula e acúmulo de nitrato em função da adubação nitrogenada. Revista Brasileira de Ciencias Agrarias 6: 230-235.

TAMME, T; REINIK, M; ROASTO, M. 2010. Nitrates and nitrites in vegetables: occurrence and health risks in bioactive foods in promoting health. Academic Press 307-321.

TRANI, PE; PURQUÉRIO, LFV; FIGUEIREDO, GJB; TIVELLI, SW; BLAT, SF. 2014. Calagem e adubação da alface, almeirão, agrião d'água, chicória, coentro, espinafre e rúcula. Campinas: IAC. Available at <http://www.iac.sp.gov.br/ imagem_informacoestecnologicas/97.pdf $>$. Accessed September 10, 2020.

URLIĆ, B; DUMIČIĆ, G; ROMIĆ, M; BAN, SG. 2017. The effect of $\mathrm{N}$ and $\mathrm{NaCl}$ on growth, yield, and nitrate content of salad rocket (Eruca sativa Mill.). Journal of Plant Nutrition 40: 2611-2618.

VIEIRA FILHO, PS; OLIVEIRA, GQ; BISCARO, GA; MOTOMIYA, AVA; GEISENHOFF, LO. 2017. Fertirrigação com nitrogênio na cultura da rúcula. Agrarian 10: 304-310.

YORUK, V; DURUKAN, H; SARAC, H; DEMIRBAS, A; KARAKOY, T. 2018. The effects of different nitrogen doses on yield and nutrient uptake of rocket (Eruca sativa) plant. Scientific Papers-Series B, Horticulture 359-365. 